\title{
Argentine ant (Linepithema humile, Mayr) eradication efforts on San Clemente Island, California, USA
}

\author{
Korie C. Merrill $1,5,{ }^{*}$, Christina L. Boser ${ }^{2}$, Cause Hanna ${ }^{3, \dagger}$, David A. Holway ${ }^{4}$, \\ Ida Naughton ${ }^{4}$, Dong-Hwan ChoE ${ }^{5}$, and Erin E. Wilson Rankin ${ }^{5}$ \\ ${ }^{1}$ Soil Ecology and Restoration Group, San Diego State University, San Diego, CA \\ ${ }^{2}$ The Nature Conservancy, San Francisco, CA \\ ${ }^{3}$ California State University Channel Islands, Camarillo, CA \\ ${ }^{4}$ Division of Biological Sciences, University of California, San Diego, CA \\ ${ }^{5}$ Department of Entomology, University of California, Riverside, CA
}

\begin{abstract}
The Argentine ant, Linepithema humile (Mayr), is a highly invasive ant species that has spread into urban, agricultural, and natural areas worldwide. The pervasive expansion of this species is detrimental both ecologically and economically, resulting in the allocation of vast amounts of resources for control. New efforts are underway to control the Argentine ant in ecologically sensitive habitats, such as those on the California Channel Islands. We tested the efficacy of thiamethoxam liquid bait at a concentration of $6 \mathrm{ppm}$ on San Clemente Island, California, where the Argentine ant has spread into natural areas hosting protected endemic species. Applied by hand, helicopter, and ATV, hygroscopic polyacrylamide beads were used as a bait matrix to deliver the liquid bait (thiamethoxam and sucrose) for Argentine ant infestations at 5 sites (totaling $177 \mathrm{ha}$ ) on San Clemente Island. Treatments reduced the number of monitoring points at which the Argentine ant was detected 1 year posttreatment (17.91\% vs. 3.65\%), suggesting that these methods are a promising conservation tool. Continued monitoring to detect remaining infestations will be necessary for eventual eradication of the Argentine ant from San Clemente Island.
\end{abstract}

RESUMEN.-La hormiga argentina, Linepithema humile (Mayr), es una especie de hormiga altamente invasiva que se ha dispersado hacia zonas urbanas, agrícolas y naturales de todo el mundo. La expansión generalizada de esta especie es perjudicial tanto ecológica como económicamente, resultando en la asignación de grandes cantidades de recursos para su control. Se están llevando a cabo nuevos intentos de control de la hormiga argentina en hábitats ecológicamente sensibles como los de las Islas del Canal en California. En San Clemente, California, probamos la eficacia del cebo líquido de tiametoxam, a una concentración de 6 ppm, en áreas naturales, en donde la hormiga argentina se dispersó, y que albergan especies endémicas protegidas. En cinco sitios (un total de $177 \mathrm{ha}$ ) de la isla de San Clemente, se aplicaron gotas de poliacrilamida higroscópicas, usadas como matriz de cebo para suministrar el cebo líquido (tiametoxam y sacarosa) y detectar, así, la infestación de hormigas argentinas. La aplicación se llevó a cabo a mano, con helicópteros y con vehículos todo terreno (ATV, por sus siglas en inglés). Los tratamientos redujeron el número de puntos de monitoreo en los que se detectó la hormiga argentina un año después del tratamiento (17.91\% frente a 3.65\%), sugiriendo que estos métodos pueden ser una herramienta eficaz para la conservación. Será fundamental llevar a cabo un monitoreo continuo para detectar las infestaciones restantes y, así, eventualmente, erradicar a la hormiga argentina de la isla San Clemente.

The invasive Argentine ant, Linepithema humile (Mayr), is an ecologically destructive species, often negatively affecting native flora and fauna in its introduced ranges (Human and Gordon 1996, Holway 1998, Suarez et al. 2000, Sanders et al. 2001, Lach 2008, LeVan et al. 2014, Hanna et al. 2015a). Invasion by the Argentine ant on the California Channel Islands may be of particular concern given the number of endemic and rare taxa present
(Jenkins et al. 2015). Eradication efforts on the California Channel Islands are currently underway on 2 of the 4 islands where the Argentine ant is present (Merrill 2015, Boser et al. 2017). Here we discuss the eradication effort on San Clemente Island (SCI), the southernmost island in the archipelago.

San Clemente Island is situated approximately $125 \mathrm{~km}$ west of San Diego and $100 \mathrm{~km}$ south of Long Beach, California. The climate

*Corresponding author: korie.c.merrill@gmail.com $\dagger$ Deceased

DHC

orcid.org/0000-0003-2622-3862

EEW

orcid.org/0000-0001-7741-113X 
is characterized as Mediterranean, with dry summers and rain in winter (Kimura 1974, Yoho et al. 1999). Since 1934, SCI has been owned and managed by the U.S. military as a training area. Despite its isolation from the mainland, SCI was not immune to the invasion of Argentine ants and became the focus of eradication efforts.

The Argentine ant was first detected on SCI in 2008 at Wilson Cove (Fig. 1). The infestation at Wilson Cove was delineated in 2011, at which time another infestation was discovered at the airfield that was subsequently delineated in 2012. As of May 2015, 11 infested sites have been detected and mapped, totaling 477 ha and individually ranging in size from 0.2 ha to 223 ha (including a 50-m buffer for detection error). Although the exact mode and timing of Argentine ant introduction to SCI are unknown, the lack of winged queen dispersal in this species makes inadvertent introduction by human activity the only likely scenario for introduction. For example, 10 out of 11 infested sites are closely associated with regular human disturbance or occupation, such as buildings, roads, and other construction activities. The remaining site, Larkspur, is a vegetation restoration site embedded within the natural landscape. The Argentine ant was likely introduced to this latter site via infested container plants transported from a nursery located within the Wilson Cove infestation in 2008 and 2010. Known and accessible restoration planting sites on SCI were monitored for Argentine ant infestations in 2013 and 2014 , as well as opportunistically during subsequent site maintenance and monitoring. It was during one of these monitoring visits in 2016 that Argentine ants were discovered at the Larkspur planting site. Despite the association with human activity, all of the large infestations on SCI are spreading into adjacent natural areas composed of native shrubs and nonnative grasses.

Although the ecological effects of Argentine ant invasions have not been studied in detail on SCI, documented impacts on Santa Cruz Island include the displacement of native ants (Hanna et al. 2015a) and the disruption of pollination mutualisms (Hanna et al. 2015b). Continued invasion by the Argentine ant on SCI thus represents a conservation concern. Overall, SCI is home to 38 described endemic taxa (14 plants and 22 animals) including 6 federally listed plant species and 3 federally listed bird taxa (Raven 1963, Jorgensen and Ferguson 1984). SCI supports 14 native ant species, several of which appear to represent morphologically differentiated taxa unique to SCI and at least 1 species (Aphaenogaster patruelis) that is endemic at the species level to the southern Channel Islands and Isla Guadalupe. Invaded areas on SCI typically support no other native ant species other than Monomorium ergatogyna, a common species found on all 8 Channel Islands and the adjacent mainland. The ability of the Argentine ant to disrupt pollination mutualisms is of concern given that existing Argentine ant infestations overlap populations of 2 federally listed plant taxa (Acmispon dendroideus traskiae [San Clemente Island lotus] and Delphinium variegatum kinkiense [San Clemente Island larkspur]). An additional impact associated with Argentine ant invasions is a reduction in the food supply of species that consume native ants (Suarez et al. 2002). This type of impact could affect the island fox (Urocyon littoralis) (Phillips et al. 2007), the island night lizard (Xantusia riversiana), and the federally listed San Clemente Bell's Sparrow (Amphispiza belli clementeae).

We describe one treatment phase of the Argentine ant eradication program on SCI and report on its efficacy. Treatment protocols described here were implemented on SCI in 2014 and 2015 and largely emulate earlier work conducted on Santa Cruz Island, California (Boser et al. 2014, Rust et al. 2015, Boser et al. 2017). These protocols include the use of baits (i.e., hygroscopic polyacrylamide beads saturated with a sucrose solution and 6 ppm thiamethoxam) deployed via helicopter. We discuss potential modifications to our approach that may improve future eradication efforts in sensitive natural areas that are infested with the Argentine ant.

\section{METHODS}

Based on laboratory efficacy experiments conducted by The Nature Conservancy and Dr. Michael Rust at the University of California, Riverside, an aqueous 25\% (w/v) sucrose solution containing Optigard ${ }^{\circledR}$ Flex Insecticide (Syngenta Crop Protection LLC, Greensboro, NC; $21.6 \%$ thiamethoxam) at $0.0006 \%$ (6 ppm) 


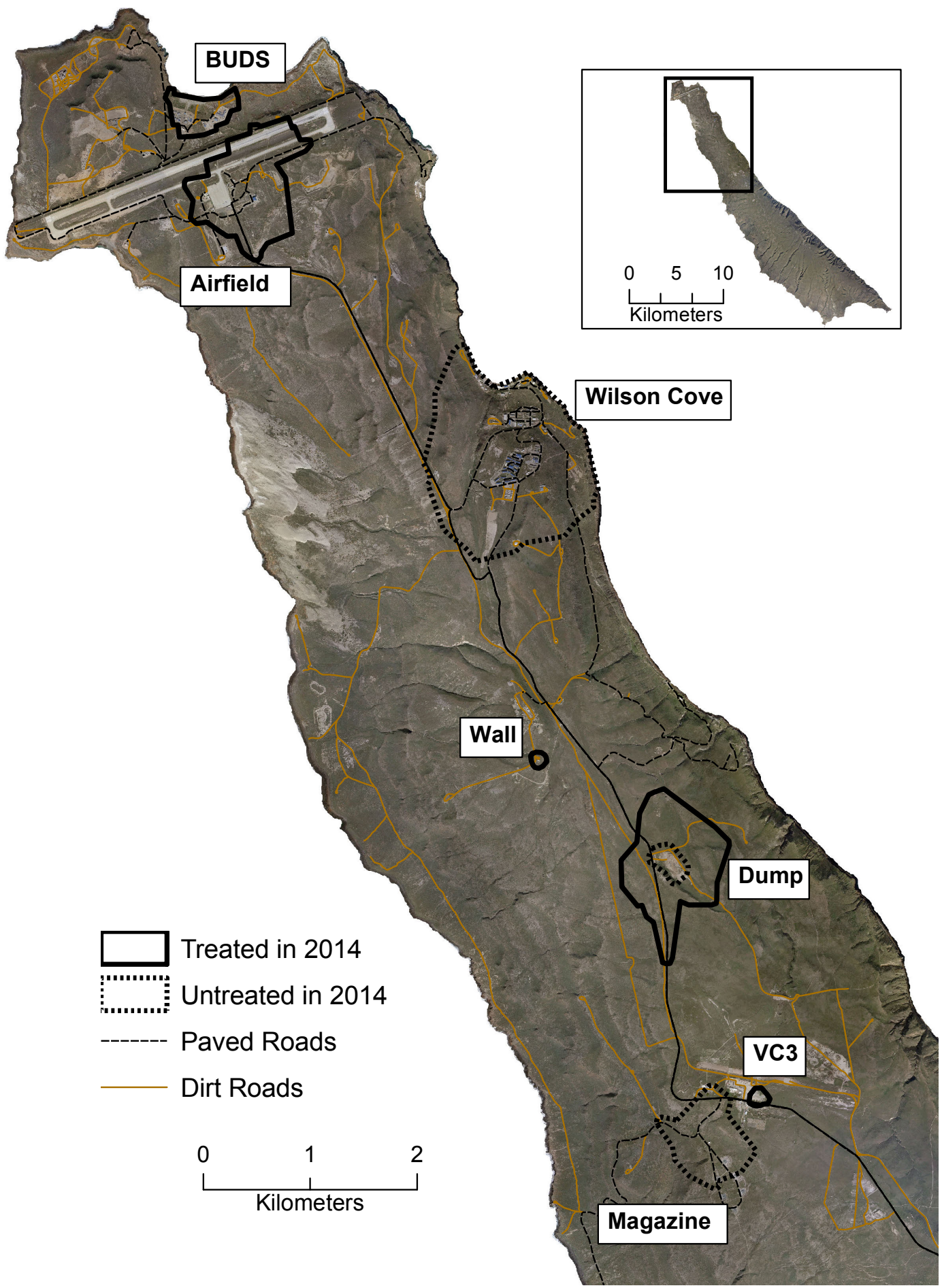

Fig. 1. Argentine ant (Linepithema humile) infestations on San Clemente Island in 2014. Five Argentine ant infestations were treated in 2014 , two were monitored as control sites, and the interior of the dump, an active landfill, was not treated. San Clemente Island is located off of the southern California coast. The island is $35 \mathrm{~km}$ long and $6.67 \mathrm{~km}$ at its widest point, totaling an area of $145 \mathrm{~km}^{2}$. 
TABLE 1. Number of bait deployments and treatment dates of ant-infested areas in 2014. Number and timing of treatments depended on access to sites.

\begin{tabular}{|c|c|c|c|}
\hline $\begin{array}{l}\text { Site } \\
\text { name }\end{array}$ & Area (ha) & $\begin{array}{c}\text { No. of bait } \\
\text { deployments }\end{array}$ & $\begin{array}{l}2014 \\
\text { treatment period }\end{array}$ \\
\hline Airfield & $65.0^{\mathrm{a}}$ & 7 & August-November \\
\hline BUDS & 18.5 & 6 & August-November \\
\hline Dump & 89.4 & 7 & August-November \\
\hline VC3 & 2.4 & 9 & April-November \\
\hline Wall & 1.7 & 7 & July-November \\
\hline
\end{tabular}

aArea does not include the airfield tarmac, which was not treated.

thiamethoxam was used as a liquid bait (Boser et al. 2014, Rust et al. 2015). Hygroscopic polyacrylamide beads (Magic Beads Inc., Miami, FL) were added to this liquid solution and left to hydrate for approximately $24 \mathrm{~h}$. Hydrated beads hold the liquid bait in place, allowing it to be broadcast over a large area at a predetermined application rate (Boser et al. 2014, Buczkowski et al. 2014). As per the Optigard Flex Insecticide label restrictions described in the experimental use permit, we prepared enough hydrated beads to broadcast at a density of approximately 11 polyacrylamide bait beads per square meter or approximately $0.013 \mathrm{~L} / \mathrm{m}^{2}$ per treatment.

In 2014, five infested sites (BUDS, Airfield, Wall, Dump, and VC3) totaling 177 ha (Fig. 1) were treated with the thiamethoxam bait beads. Sites were treated 6-9 times (Table 1). Variation in the number of treatments across sites resulted from limited access to certain sites and logistical constraints involved with working on a remote island. Early treatment at VC3 (April) was implemented to elucidate potential nontarget effects on wildlife in the area (not discussed here) prior to large-scale deployment of treatments.

The 2 largest infestations at the Airfield and Dump were treated aerially by Aspen Helicopters, Inc. (Oxnard, CA) using a 284-L hopper long-lined from a helicopter. Both sites were treated on the same day multiple times during the season, with the total duration of the deployments varying from $6 \mathrm{~h}$ to $8 \mathrm{~h}$ for each deployment. The pilot controlled the amount of bait applied by adjusting the hopper aperture. Each load of bait was distributed across the site in swaths of $40 \mathrm{~m}$. To ensure complete coverage of infested sites, tracks of areas treated were recorded with handheld GPS units (eTrex 20, Garmin Ltd., Olathe, KS) or an airplane GPS unit controlled by the pilot and mapped using ArcMap 10.2.2 (Esri, Redlands, CA).

Unlike the Dump infestation which was exclusively treated using a helicopter, the perimeters of roads and buildings (up to a 30-m buffer) at the Airfield infestation were treated by a combination of hand and all-terrain vehicle (ATV) deployment. These nonaerial distribution methods prevent the delivery of bait beads to nontarget areas such as the tarmac or vehicles. To deploy bait beads by hand, technicians walked in parallel lines approximately 6-9 $\mathrm{m}$ apart while distributing bait using a chest and handheld broadcast spreader (18-L capacity, EarthWay Inc. Bristol, IN). To treat large areas along roads and inside the Airfield taxiway, an ATV with a 41.7-L motorized hopper with a deployment swath of $12 \mathrm{~m}$ was used to deploy bait beads.

Three smaller infestations (BUDS, Wall, and VC3) were treated with the bait beads using a combination of hand and ATV deployment protocols as previously described. Wall and VC3 were treated earlier than BUDS due to limited accessibility at the latter site. The BUDS infestation encompassed an active military training site, including a beach, housing, a cafeteria, and a staging area for construction materials. Due to frequent military training activities that limited the use of polyacrylamide bait beads, the beach areas within BUDS were treated with bait stations. Bait stations consisted of $15-\mathrm{mL}$ centrifuge tubes (Celltreat Polypropylene Centrifuge Tube, Celltreat, Shirley, MA) filled with $10 \mathrm{~mL}$ of $25 \%$ sucrose solution containing thiamethoxam (6 ppm). Three polyacrylamide hydrogel beads were placed inside the tube to retain moisture and to provide substrates from which ants could access the bait. Bait stations were then placed along the coast and secured with rocks to prevent spillage and sun exposure. Forty-five bait stations were placed $50 \mathrm{~m}$ apart in a single transect along the beach and left for 1 week. These bait stations were deployed twice in 2014, once in August and once in September.

To determine the efficacy of the treatments, we conducted point-count monitoring before and after treatment at all treated sites (BUDS, Airfield, Wall, Dump, and VC3). To provide a control comparison, we also monitored 2 nontreated invaded sites (Wilson Cove and Magazine), which were selected based on 
the presence of the Argentine ant, accessibility, and adequate infestation size to obtain a sufficient number of monitoring points. Monitoring points were established in microenvironments favorable to the Argentine ant. To determine Argentine ant presence, we placed a monitoring trap (a $50-\mathrm{mL}$ centrifuge vial [Celltreat] containing a cotton ball soaked with $25 \%[\mathrm{w} / \mathrm{v}]$ sucrose water $[\sim 4.5 \mathrm{~g}])$ within $5 \mathrm{~m}$ of each established monitoring point. We placed traps on the ground in areas with shrubs, subshrubs, or thick ground cover (e.g., Opuntia littoralis [prickly-pear cactus], Calystegia macrostegia amplissima [Island morning glory], thick grass [typically Bromus spp.], Atriplex semibaccata [Australian saltbush], Baccharis pilularis consanguinea [Coyote brush], Lycium californicum [California boxthorn], and Rhus integrifolia [Lemonade berry]). Each trap vial was labeled with the point number at which it was placed. After 1.0-1.5 h, vials were collected, capped, and frozen. Absence or presence of ants in the trap was recorded. Monitoring points were overlaid in a grid of each site. At small sites $(<12$ ha) such as VC3 and Wall, points were spaced $20 \mathrm{~m}$ apart, whereas monitoring points were spaced $50 \mathrm{~m}$ apart at the larger BUDS, Dump, Airfield, Wilson Cove, and Magazine (>12 ha) sites. This spacing resulted in a total of 593 monitoring points distributed across all treated sites each year and 239 monitoring points distributed across the control sites at Wilson Cove and Magazine. We adjusted the monitoring point spacing to reflect the size of different infestations to ensure that smaller sites had a sufficient number of points to detect differences in Argentine ant activity. Wildlife breeding seasons, accessibility, and weather conditions unexpectedly prevented some monitoring points from being used, leading to a $12 \%-31 \%$ reduction in the number of monitoring points per site per sampling period.

All sites were monitored twice before the treatment (at least 1 week apart), once during the treatment season, once at the end of the season in November 2014 (2 weeks after the last bait deployment), and once 1 year posttreatment in August 2015. The data (i.e., proportions of monitoring traps with Argentine ants present) were analyzed using Pearson's chi-square test ( $\mathrm{R}$ v.3.1.2, The R Foundation for Statistical Computing, 2014).

\section{RESULTS}

Pretreatment activity levels varied from site to site. The Argentine ant was detected at $20.22 \%(36 / 178)$ of monitoring points at the Airfield, $18.38 \%$ (43/234) of monitoring points at the Dump, $0 \%(0 / 29)$ of monitoring points at BUDS, $2.94 \%$ (1/34) of monitoring points at Wall, and $33.33 \%(11 / 33)$ of monitoring points at VC3 in the first round of monitoring in 2014. At untreated control sites, the Argentine ant was detected at $10.00 \%$ (9/90) of monitoring points at Wilson Cove and 6.67\% (7/105) at Magazine (Fig. 2).

Ant activity levels across 4 of the 5 sites were reduced with treatment; at the fifth, BUDS, the Argentine ant went undetected at monitoring points before and after treatment. One year following treatment (August 2015), peak Argentine ant activity was significantly reduced relative to pretreatment activity levels across the 5 treated sites $\left(\chi^{2}=104.17, \mathrm{df}=1\right.$, $P<0.01)$. We did, however, locate a small number of residual infestations in posttreatment monitoring (Fig. 2). In November 2014 we found the Argentine ant at 2 monitoring points at the Airfield infestation. In August 2015 we detected the Argentine ant at 3.65\% (19/520) of all monitoring points (18 points at the Airfield and 1 point at the Dump) at the 5 treated sites (Fig. 2). In contrast, we detected the Argentine ant at $42.08 \%$ (85/202) of monitoring points at untreated control sites in August 2015, a significant increase from the previous year $\left(\chi^{2}=56.30, \mathrm{df}=1, P<0.01\right)$.

\section{Discussion}

Historically, the eradication of invasive species has proven both costly and difficult, with only a small percentage of eradication programs achieving success (Liebhold et al. 2016). Eradications that tend to be successful usually target mammals on islands (Courchamp et al. 2003, Howald et al. 2007, Hoffmann 2010). In contrast, eradication efforts targeting introduced arthropods appear less successful. Liebhold et al. (2016), for example, examined the global eradication and response database (GE/RDA) and found evidence of 508 successful arthropod eradications, 120 failures, and 132 programs in which the outcome was unknown. Only 66\% (144/218) of reported ant eradication programs worldwide have been successful (Hoffmann et al. 2016). Success 

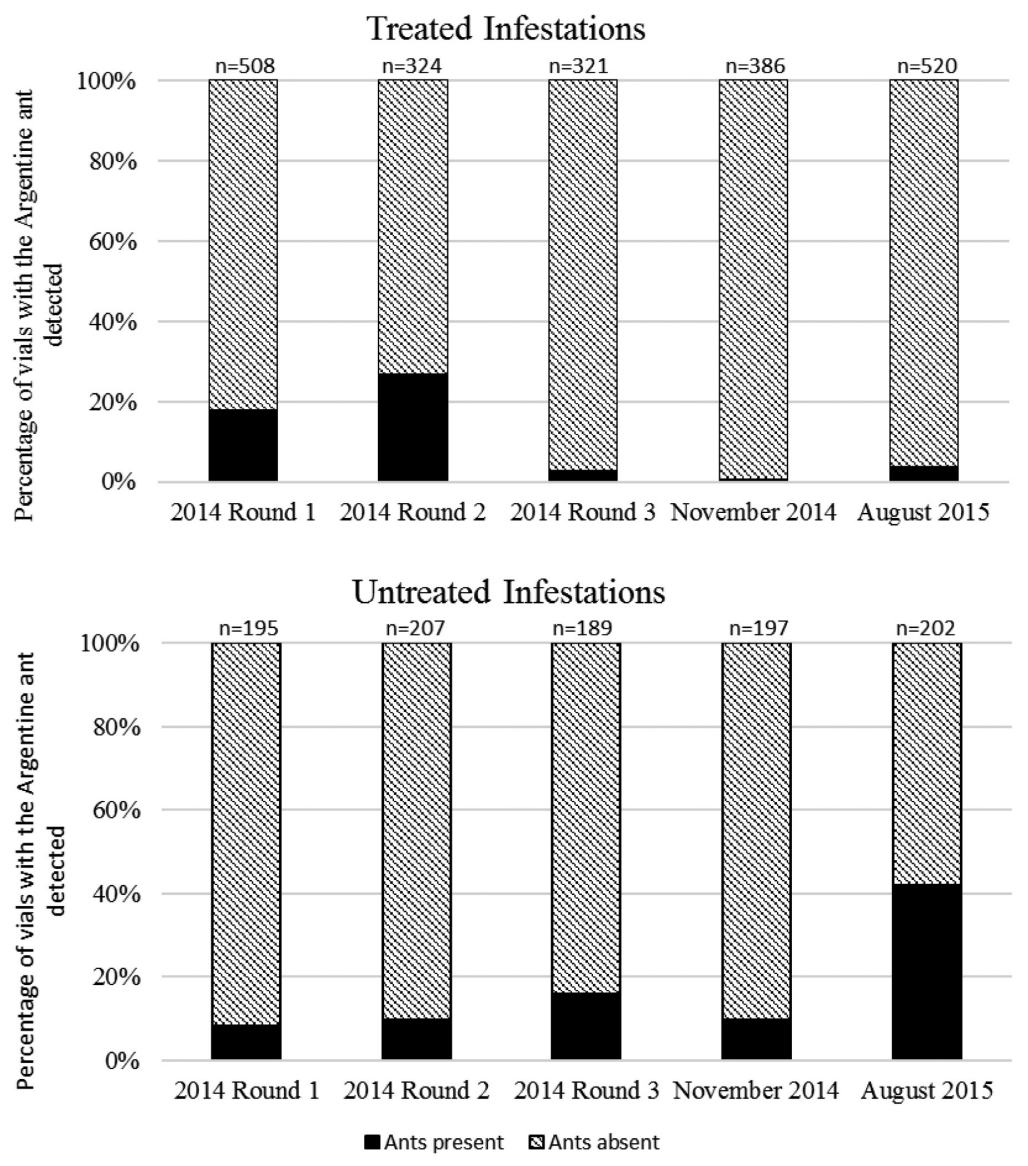

Fig. 2. Argentine ant activity. The percentage of monitoring traps in which the Argentine ant was either present or absent. Point-count monitoring was conducted twice prior to treatment (Rounds 1 and 2), during treatment (Round 3), 2 weeks posttreatment (November 2014), and 1 year posttreatment (August 2015). Data was pooled from all treated sites (top) and untreated sites (bottom).

may be overestimated due to low reporting rates of failures or negative data and the lack of sufficient monitoring to verify eradication.

The difficulties inherent in eradicating introduced ants may explain why fewer attempts have been made to eradicate ants than mammals (e.g., 218 ant eradication programs vs. 1200 mammal eradication programs) and why ant eradication programs appear less successful (Hoffmann et al. 2016). The Argentine ant proves to be no exception and may be particularly difficult to eradicate because it is polygynous (more than 1 queen per nest), unicolonial (multiple nests cooperate to form a single colony), and can form high-density infestations that will monopolize resources and quickly populate new areas (Holway et al. 2002, Tsutsui and Suarez 2003).
These life history traits, however, can be leveraged to eradicate this invasive species. Bait beads, for example, were broadcast over the entire infestation rather than targeting nests or trails as typically done in urban pest management. This approach targets the Argentine ant's ability to form high-density infestations and to monopolize resources. Moreover, our approach appears to be suitable for treating natural areas where nest and resource locations are not as apparent as in urban settings.

We observed Argentine ants foraging on the thiamethoxam-laced bait beads within $10 \mathrm{~min}$ of deployment. After $24 \mathrm{~h}$, however, few to no Argentine ant workers were seen on bait beads. This reduction in feeding activity was likely due to the beads drying out, which makes the surface of bait beads viscid and 
difficult for ants to feed on. Rust et al. (2015) showed that hygroscopic polyacrylamide baits lose attractiveness to ants when a bead loses $50 \%$ of its water content. In the laboratory, bait attractiveness significantly declined after $36 \mathrm{~h}$ at $75 \%$ relative humidity (Rust et al. 2015). The average relative humidity near the treated sites on SCI during aerial treatment ranged from $44.1 \%$ to $85.4 \%$ (http://mesowest utah.edu/). Other biotic and abiotic conditions in which the applied bait beads were placed (e.g., contact with dry soil, feeding by ants) also may have caused beads to dry out within $24 \mathrm{~h}$ of deployment. Future bait deployments should be made later in the day to avoid high daytime temperatures and to reduce bead exposure to the sun, thus potentially prolonging bait attractiveness.

Overall the treatment methods described here were successful in substantially reducing Argentine ant activity. Based on posttreatment monitoring conducted 2 weeks following the last treatments (i.e., November 2014), the only monitoring points with residual ant activity were found at the Airfield infestation. Although these infestations are most likely persisting in spite of treatment, the Airfield is notable for the large number of personnel, supplies, and aircrafts that travel between SCI and the mainland. High levels of human activity may have resulted in the accidental reintroduction of the Argentine ant to this location. Hoffmann et al. (2017) speculate that it could take a decade to demonstrate the success of a biosecurity program. On SCI, biosecurity and prevention should be a priority even while eradication efforts are underway. For example, instituting protocols to monitor freight and aircraft for the Argentine ant prior to leaving the mainland may significantly decrease the chance of future reintroductions.

It is likely that the remnant ant activity at the Airfield and the Dump is due to insufficient treatment, potentially compounded by reintroductions. This study highlights the importance of sufficient reapplication of the treatment and modifying protocols to fit the local landscape. In 2014 the goal on SCI was to treat each infestation 12 times in 1 year, as proposed in Boser et al. (2014) and Rust et al. (2015). Due to the problematic nature of conducting eradication efforts on an active military base-most notably scheduling airspace and delivering supplies-the sites on SCI were treated 9 times at most. On Santa Cruz Island, infestations were treated biweekly 12 times in 2013, and no Argentine ants were found in concentrated monitoring efforts conducted the following year (Boser et al. 2017). Subsequent monitoring conducted in 2015 at these same Santa Cruz Island sites revealed 1 localized ( $0.3 \mathrm{ha}$ ) infestation that may have persisted because of trees that blocked bait delivery (Boser et al. 2017). Based on the results from Santa Cruz Island, a biweekly deployment of 12 rounds of treatments within a season seems like a minimum approach needed to eliminate the Argentine ant. Subsequent treatment of all infestations on SCI is recommended in order to increase the likelihood of a successful eradication.

In addition to subsequent treatments, further research on developing low-density monitoring protocols is necessary to improve the likelihood of Argentine ant eradication because small infestations of this species are difficult to find, particularly in areas where infestations are widely distributed (Courchamp et al. 2003, Hoffmann 2010). Accurate detection of any remaining ant activity is a critical step for effective follow-up treatments and full eradication of this species on SCI. Future research on the San Clemente and Santa Cruz Islands will investigate novel approaches to locating small Argentine ant infestations, including improving bait trap designs and lures as well as using detection dogs in the field to maximize detection probability and to reduce project costs.

\section{ACKNOWLEDGMENTS}

This project was funded by a cooperative agreement (N62470-13-2-8022) with the Naval Facilities Engineering Command. Pesticide was provided by Syngenta Crop Science. Thank you to the 2 anonymous reviewers for their input on this manuscript. We thank the following for their edits and support throughout this project: Melissa Booker, Aaron Hebshi, Jeffery Diez, Matthew Daugherty, and C. Sheena Sidhu. Thank you to the SERG research technicians who conducted the fieldwork: Amanda Chisholm, Calypso Gagorik, Armando Aispuro, and Stephanie Calloway.

\section{Literature Cited}

Boser, C.L., C. Hanna, K.R. Faulkner, C. Cory, J.M. Randall, AND S.A. Morrison. 2014. Argentine ant 
management in conservation areas: results of a pilot study. Monographs of the Western North American Naturalist 7:518-530.

Boser, C.L., C. Hanna, D.A. Holway, K.R. FaulKner, I Naughton, K. Merrill, J.M. Randall, C. Cory, D.-H. Choe, and S.A. Morrison. 2017. Protocols for Argentine ant eradication in conservation areas. Journal of Applied Entomology 141:540-550.

Buczkowski, G., E. Roper, And D. Chin. 2014. Polyacrylamide hydrogels: an effective tool for delivering liquid baits to pest ants (Hymenoptera: Formicidae). Journal of Economic Entomology 107:748-757.

Courchamp, F., J.L. Chapuis, and M. Pascal. 2003. Mammal invaders on islands: impact, control and control impact. Biological Reviews 78:347-383.

Hanna, C., I. Naughton, C.L. Boser, R. Alarcón, K.-L.J. Hung, D.A. Holway. 2015a. Floral visitation by the Argentine ant reduces bee visitation and plant seed set. Ecology 96:222-230.

Hanna, C., I. Naughton, C. Boser, and D.A. Holway. 2015b. Testing the effects of ant invasions on non-ant arthropods with high-resolution taxonomic data. Ecological Applications 25:1841-1850.

Hoffmann, B.D. 2010. Ecological restoration following the local eradication of an invasive ant in northern Australia. Biological Invasions 12:959-969.

Hoffmann, B.D., R. Graham, and D. Smith. 2017. Ant species accumulation on Lord Howe Island highlights the increasing need for effective biosecurity on islands. NeoBiota 34:41-52.

Hoffmann, B.D., G.M. LuQue, C. Bellard, N.D. Holmes, AND C.J. DONLAN. 2016. Improving invasive ant eradication as a conservation tool: a review. Biological Conservation 198:37-49.

Holway, D.A. 1998. Effect of Argentine ant invasions on ground-dwelling arthropods in northern California riparian woodlands. Oecologia 116:252-258.

Holway, D.A., L. LaCh, A.V. Suarez, N.D. Tsutsui, and T.J. CASE. 2002. The causes and consequences of ant invasions. Annual Review of Ecology, Evolution, and Systematics 33:181-233.

Howald, G., C.J. Donlan, J.P. Galván, J.C. Russell, J. Parkes, A. Samaniego, Y. Wang, D. Veitch, P. Genovesi, M. PASCAL, ET AL. 2007. Invasive rodent eradication on islands. Conservation Biology 21: $1258-1268$.

Human, K.G., AND D.M. Gordon. 1996. Exploitation and interference competition between the invasive Argentine ant, Linepithema humile, and native ant species. Oecologia 105:405-412.

Jenkins, C.N., K.S. Van Houtan, S.L. Pimm, and J.O. SEXTON. 2015. US protected lands mismatch biodiversity priorities. Proceedings of the National Academy of Sciences 112:5081-5086.

Jorgensen, P.D., And H.L. Ferguson. 1984. The birds of San Clemente Island. Western Birds 15:111-130.

Kimura, J.C. 1974. Summary of knowledge of the southern California coastal zone and offshore areas. Physical Environment 1:1-70.
LACH, L. 2008. Argentine ants displace floral arthropods in a biodiversity hotspot. Diversity and Distribution $14: 281-290$

LeVan, K.E., K.-L.J. Hung, K.R. McCann, J.T. LudKa, AND D.A. Holway. 2014. Floral visitation by the Argentine ant reduces pollinator visitation and seed set in the coast barrel cactus, Ferocactus viridescens. Oecologia 174:163-171.

Liebhold, A.M., L. Berec, E.G. Brokerhoff, R.S. Epanchin-Niell, A. Hastings, D.A. Herms, J.M. Kean, D.G. McCullough, D.M. Suckling, P.C. ToBin, AND T. YamanaKa. 2016. Eradication of invading insect populations: from concepts to applications. Annual Review of Entomology 61:335-352.

MerriLl, K.C. 2015. Management and monitoring of Linepithema humile (Mayr) on San Clemente Island. Master's thesis, University of California Riverside, CA.

Phillips, R.B., C.S. Winchell, and R.H. Schmidt. 2007. Dietary overlap of an alien and native carnivore on San Clemente Island, California. Journal of Mammalogy 88:173-180.

Raven, P.H. 1963. A flora of San Clemente Island, California. Aliso: A Journal of Systematic and Evolutionary Biology 5:289-347.

Rust, M.K., A. Soeprono, S. Wright, L. Greenberg, D.H. Choe, C. Boser, C. Cory, and C. Hanna. 2015. Laboratory and field evaluations of polyacrylamide hydrogel baits against Argentine ants (Hymenoptera: Formicidae). Journal of Economic Entomology 108: $1228-1236$.

Sanders, N.J., K.E. Barton, and D.M. Gordon. 2001. Long-term dynamics of the distribution of the invasive Argentine ant, Linepithema humile, and native taxa in northern California. Oecologia 127:123-130.

Suarez, A.V., J.Q. Richmond, And T.J. Case. 2000. Prey selection in horned lizards following the invasion of Argentine ants in Southern California. Ecological Applications 10:711-725.

Suarez, A.V., A.V. Suarez, D.A. Holway, D. Liang, N.D. Tsutsui, and T.J. Case. 2002. Spatiotemporal patterns in intraspecific aggression in the invasive Argentine ant. Animal Behaviour 64:697-708.

Tsutsui, N.D., AND A.V. Suarez. 2003. The colony structure and population biology of invasive ants. Conservation Biology 17:48-58.

Yoho, D., T. Boyle, And E. Mcintire. 1999. The climate of the Channel Islands, California. Pages 81-88 in Proceedings of the Fifth California Islands Symposium, Santa Barbara, Calif., 29 March-1 April 1999. Santa Barbara Museum of Natural History, Santa Barbara, California.

Received 1 March 2017

Revised 22 August 2017

Accepted 9 September 2017

Published online 29 March 2018 